Case for Teaching

\title{
Bia Brazil: Activewear Made in Brazil to the World
}

Bia Brazil: Moda Esportiva Feita no Brasil para o Mundo

\author{
Masaaki Kotabe ${ }^{10}$ \\ Moema Pereira Nunes ${ }^{2} \odot$ \\ Fernanda Kalil Steinbruch ${ }^{3} \bullet$
}

\section{INTRODUCTION}

Beatriz arrives at Bia Brazil office in Porto Alegre. She walks around realizing how many boxes are ready to be shipped today. Yesterday employees worked until very late to prepare all these orders. She starts looking at the destinations: Switzerland, Iran, Thailand, Mexico, USA, Finland, and Japan. So many different destinations... She has a flashback of the early days of Bia Brazil looking at the boxes. At the same time, she asks herself how the company has grown so much abroad but remains so small inside the Brazilian market. She asks: "What should we do?" "What are we missing?"

While she is asking herself, a new intern just came into the office. Alice looks surprised to see Beatriz. It's her second day at Bia Brazil and she is so excited about the internship. Alice studied Bia Brazil's history and she is impressed with the company. Since its foundation in 1994, the company has sought to serve the global market, and to be a pioneer among small Brazilian companies in the use of e-commerce as a sales channel. Over the years, the company

1. Temple University, The Fox School of Business, Philadelphia, PA, USA.

2. Universidade FEEVALE, Instituto de Ciências Sociais Aplicadas, Novo Hamburgo, RS, Brazi

3. Universidade Federal do Rio Grande do Sul, Escola de Administração, Porto Alegre, RS, Brazil.

Cite as: Kotabe, M., Nunes, M. P., \& Steinbruch, F. K. (2021). Bia Brazil: Activewear made in Brazil to the world. Revista de Administração Contemporânea, 25(2), e190357. https://doi.org/10.1590/1982-7849rac2021 190357.en

\# of invited reviewers until the decision:

$1^{\text {st }}$ round
$2^{\text {nd }}$ round
$3^{\text {rd }}$ round
$4^{\text {th }}$ round

\begin{tabular}{lllllllll}
2 & 3 & 4 & 5 & 6 & 7 & 8 & 9 \\
$\frac{0}{0}$ & & & & & & & & \\
\hline 0 & & & & & & & & \\
\hline
\end{tabular}

JEL Code: L67, L83, Z2

Editor-in-chief: Wesley Mendes-Da-Silva (Fundação Getulio Vargas, EAESP, Brazil) (1) Associate Editor: Paula C. P. de S. Chimenti (Universidade Federal do Rio de Janeiro, COPPEAD, Brazil) Reviewers: Clarice Kogut (Universidade Federal do Rio de Janeiro, COPPEAD, Brazil) One of the reviewers chose not to disclose his/her identity

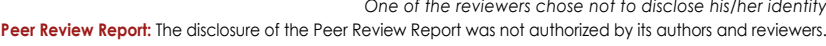
Received: October 28, 2019 Last version received: June 30,2020 Accepted: September 01, 2020 


\section{THE EARLY DAYS OF BIA BRAZIL ACTIVEWEAR}

Beatriz Wilhelm Dockhorn, or just Bia, is a former athlete, South American champion of artistic gymnastics. In 1994, after her retirement from the sport, she decided to become an entrepreneur based on the needs experienced in her own sporting environment. As an athlete, Bia had identified that there was little supply of differentiated sportswear. Most of the sports outfits had extremely traditional and unattractive style and design, especially for female athletes. Thus, Bia felt disappointed at the lack of clothes through which the professionals could express themselves, and, at the same time, have more comfort and quality. "Being a former athlete, I knew what was missing in the market in other countries, because I traveled a lot representing Rio Grande do Sul (state) and Brazil. We create products based on this knowledge."

Two challenges arose immediately. The first included the establishment of a manufacturing facility and, to overcome it, the beginning was modest: production in a space available on the ground floor of her own house. However, there was another challenge, namely: how to market these clothes? Unlike many entrepreneurs of her generation, Bia was fortunate as she had been acclimated to the international environment since she was very young because of sport. She also sensed that the need for differentiated sportswear did not only exist in her city but also in several places around the world. She knew that her network of personal relationships, developed throughout her career as an athlete, would allow her to reach these potential markets. Her greatest impasse was how to get there with limited resources and at a time when a talk of market globalization was only beginning in Brazil. The solution came through a technology that was emerging in the business environment at that time: the internet.

Thus, in 1994, Bia Brazil Activewear was founded: a company created by an entrepreneur with a global market vision and based on innovative practices, in a period when very little was said about the importance of these characteristics in the business environment. In fact, if the establishment of a physical store was out of the entrepreneur's financial reach, and the potential markets were too scattered, the internet conferred an opportunity.

Initially, the company developed a very simple website in Portuguese, and it was already translated into two other languages (English and Spanish). The virtual environment became the platform for the dissemination of products designed by Bia herself. While competing around the world, she realized that the sports clothes worn by the female audience abroad were almost exclusively sports coats of renowned brands such as Nike, Adidas and
Reebok; all similar to each other. In these international trips, what caught her attention was the similarity of the styles of these sports coats for men and women, and particularly the lack of femininity designed into women's sports coats. In her words: "Men and women used the same sports coat, without any difference. I thought that was horrible: In a way, the husband and wife looked the same. (The sport coat) did not shape the woman in any form". From the very first moment, the design became a strong element in the company's product strategy, which was then presented to the whole world through the company's website.

Beatriz was not sure if she was going to sell direct to customers or to representatives and stores. Everything was a learning-process and she tried to keep her mind open. As a result, the company suddenly turned its focus to $\mathrm{B} 2 \mathrm{~B}$ as she started to receive requests from companies from abroad. The first one came from Costa Rica in 1996. The customer, who had seen the online products, requested price information and, without any knowledge of export price formation, Beatriz only reported the cost of the pieces converted to foreign currency: US\$ 350 . A few days later, she received a call from Banco do Brasil informing the existence of an international payment order in the name of her company. However, she did not know what that meant, or even how to deal with customs and logistics. For a total sale of US\$ 350, the company had a total expense of US\$250. "I did not calculate ... I wanted to export. I saw an opportunity and went for it." It is not difficult to conclude that this first transaction resulted in a huge loss for the company. Besides ignoring the export procedures, it was noticed that the company's products also did not have the quality standard that the foreign market demanded. Problems in the manufacture meant that products were delivered without the quality required and expected by the customers. Products began to split at the seam during use. The customers demanded that the company exchange the sub-par products for new ones. These products experienced the same problem and Beatriz decided to look for a better sewing process. The solution was to import German sewing machines that used three threads instead of the traditional two. As a result, product quality was improved, and a new batch of products was sent to the Costa Rican customer. However, instead of giving up the foreign market, the reaction was the opposite: Bia used this problem as a learning experience.

While implementing improvements in its product line and acquiring knowledge on export operations, the company officially became an exporter. In the sequence, Bia Brazil started to export to other Central American countries. The entry into the United States was an opportunity caused by an unethical behavior from another Brazilian company in 2003. Beatriz identified that there 
was a potential client and visited the company in USA in order to start the negotiation. Besides the difficulties faced because of the lack of trust in a new Brazilian supplier, Beatriz slowly developed a good relationship with the American client. This client remains as the Bia Brazil's main client in USA and nowadays works as a representative and distributor, being a strategic partner for the company.

Considering that it was a small company, Beatriz was responsible for all commercial activities. She learnt by handling the exports, and later with the other entry modes. For example, regarding the quality of the products, Beatriz only found it from her clients' feedback. Every time a client informed a problem, she went back to the manufacturing process in order to identify the origin of the problem, solve it, and assure that kind of problem wouldn't occur anymore.

It was also a precursor to other small Brazilian companies present in the international market. Beatriz had no idea of how innovative and daring she was until receiving a call from the Brazilian Foreign Trade Minister and an invitation to a meeting in the Federal Capital. At that meeting, the minister informed her that she was the only small Brazilian exporting company in the database with all Brazilian exporters regulated by the Federal Government. The fact is that a 'home-based' company was, at that moment, considered an embryonic form for a government policy that was under development with the purpose of nurturing small Brazilian exporting companies.

\section{THE FOUNDATION OF APEX-BRASIL DRIVES BIA BRAZIL}

Apex-Brasil (Brazilian Agency for the Promotion of Exports and Investments) was founded in 2003, with the purpose of promoting exports of Brazilian products and services. The agency works to increase the number of exporting companies and to add value to the exported products. Apex-Brasil is dedicated to providing support in the areas of information and qualification for export, commercial promotion, positioning and image, and support for internationalization, so that Brazilian businesses become increasingly prepared and successful in the foreign market.

At first, the partnership comprised Apex-Brasil financially supporting the installation of booths at international trade fairs - and the companies contributed showcasing their products. As Beatriz points out: "Where the Apex was going, I was setting up my booth, paying for the tickets and the lodging, and carrying my things (products). We started like this!"
This was a period of great learning for the company, both for the international exposure and for time shared with other managers. Due to the non-existence of small export-oriented companies, Apex-Brasil also ended up supporting larger companies with much more experience in the foreign market. As the contact with the managers intensified in these events, the businesswoman was able to acquire knowledge from these experienced professionals. Apex-Brasil paid for the booth, and the costs of travel and lodging were the responsibility of each company. A curious fact is that, on many occasions, to reduce costs for companies, the presidential airplane, whenever available, was ceded to the Agency's discretion, transporting managers and materials to international fairs. As Beatriz points out: "I learned a lot from them, with these big exporters". Beatriz considers the partnership with Apex-Brasil to be extremely positive, stating that "Apex (-Brasil) opened doors for me at a time when they were all closed". She believes that if she had to go through the internationalization process by herself, she would not have been able to go that far.

Among the actions developed in partnership with Apex-Brasil, the Formula Indy Project, focused on the North American market, stands out. During the race period, Apex-Brasil set up a booth at the racetracks, where rounds of negotiations were held between Brazilian business executives and CEOs of American companies. This was one of the opportunities that allowed Bia Brazil to grow in the North American market.

\section{THE GROWTH OF INTERNATIONAL PERFORMANCE AND A FRESH START IN 2008}

The decision to develop an international brand has brought difficulties to the company in the beginning of its trajectory due to the inherent difficulty to position its products in the foreign markets with such limited resources. "Everything takes a lot of time, especially when there is no money to do strong marketing abroad. When you work with your own brand, you have to convince the customer to sell your product and that takes time" says Beatriz.

The website created for the U.S. market turned into a platform to sell to other countries. In 2006, Bia Brazil started to export to European and Asian countries. Customers from those continents used to search for new products in North American websites. In 2017, the company started to export to the United Arabic Emirates and also made one shipment to Iran.

Even with all the difficulties, Bia Brazil has been consolidating in the international market over the years. 
Beatriz considers the knowledge of the market and networking fundamental for the company's development, claiming that these factors collaborated when contacting the Brazilian Embassy Abroad, for example, facilitating the company's entry into international markets.

One of the strengths of the company is the development of relationships with its clients abroad. This is precisely what supported the company to re-establish itself after a fire in 2008. Beatriz says that in that year, she went to the company's facility to check if any damage had occurred due to rain and strong wind. At that moment, she verified that no damage had happened, however, after she exited from the building, there was a short circuit in the electrical system on the top of the plaster lining in the factory. "(After the fire) I did not want to go back, I did not want to start over because I had lost everything. I had no insurance, so I thought: I will not go back, I will stay at home. Then my export clients started to deposit the money for what they would buy for the next year" says Beatriz. The pre-payment for the orders planned for the following year generated a sufficient demand to meet these requests from the time of its reconstruction. Beatriz did not ask the clients for a pre-payment. Actually, she informed then that she was going to close her business because of the fire, and that she was unable to deliver their previous order. Instead of just accepting that, the clients started to send her a new order with pre-payment, helping her to get the amount to rebuild Bia Brazil. The relationship developed over the years by the company was what has made Bia Brazil restructure. The first customer to make the advance payment was from the United States. Following that, the first client from Costa Rica also made the pre-payment.

Beatriz points out that this type of partnership with clients was one of the most significant differences perceived in the international context. "I understood that people, when exporting, are partners, not customers." With these pre-payments, the company was able to reestablish itself, and she further believes in the importance of developing partnerships for international growth.

\section{THE CONSOLIDATION OF THE COMPANY'S INTERNATIONAL OPERATIONS}

Bia Brazil's main marketing channel is its e-commerce, through which the company serves customers from all over the world. Bia Brazil has three websites, all following the same design (Figure 1). The Brazilian one serves clients in Brazil and all over the world. The one in Portugal is focused on that specific country. Both of them are managed by Bia Brazil. U.S. website is managed by a local partner and, besides that country, attends the customers from other countries close to the United States. The online store in the United States is managed by their representative in the country, while the Brazilian and Portuguese ones are managed by Bia Brazil. The internationalization to Europe (in 2006) and other countries was a consequence of the U.S. website, as the clients got to know Bia Brazil because of it.

The products are exported to partners in several countries that sell them in department stores (Figure 2) and/or through their online stores (Figure 3). As to the main destinations of the company's exports, the following stand out:

- South America: Chile, Peru, Uruguay, Bolivia, Colombia, Venezuela, and Paraguay.

- Central America: Costa Rica, Guatemala, El Salvador, Dominican Republic, Panama, Puerto Rico, and Honduras.

- North America: United States, Canada, and Mexico.

- Asia: China, Japan, Jordan, Thailand, India, Singapore, and Kazakhstan.

- Europe: Portugal, Spain, England, Germany, France, Switzerland, Austria, Italy, Netherlands, Romania, Iceland, Finland, Denmark, Cyprus, Belgium, Sweden, Greece, Poland, Czech Republic, Ireland, Slovenia, Norway, and Russia.

. Emirates: Dubai and Iran.

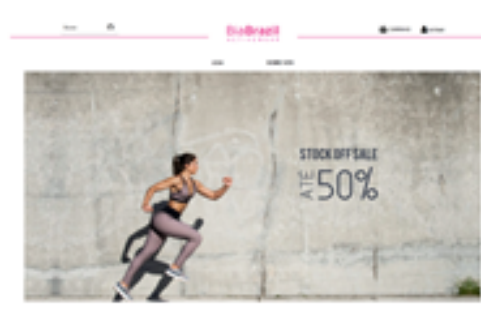

Portugal

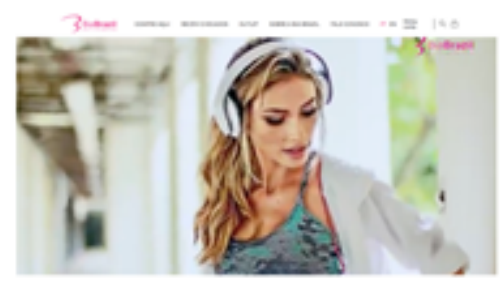

Brazil

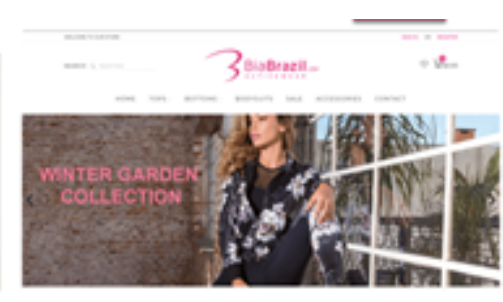

USA

Figure 1. Bia Brazil websites. 


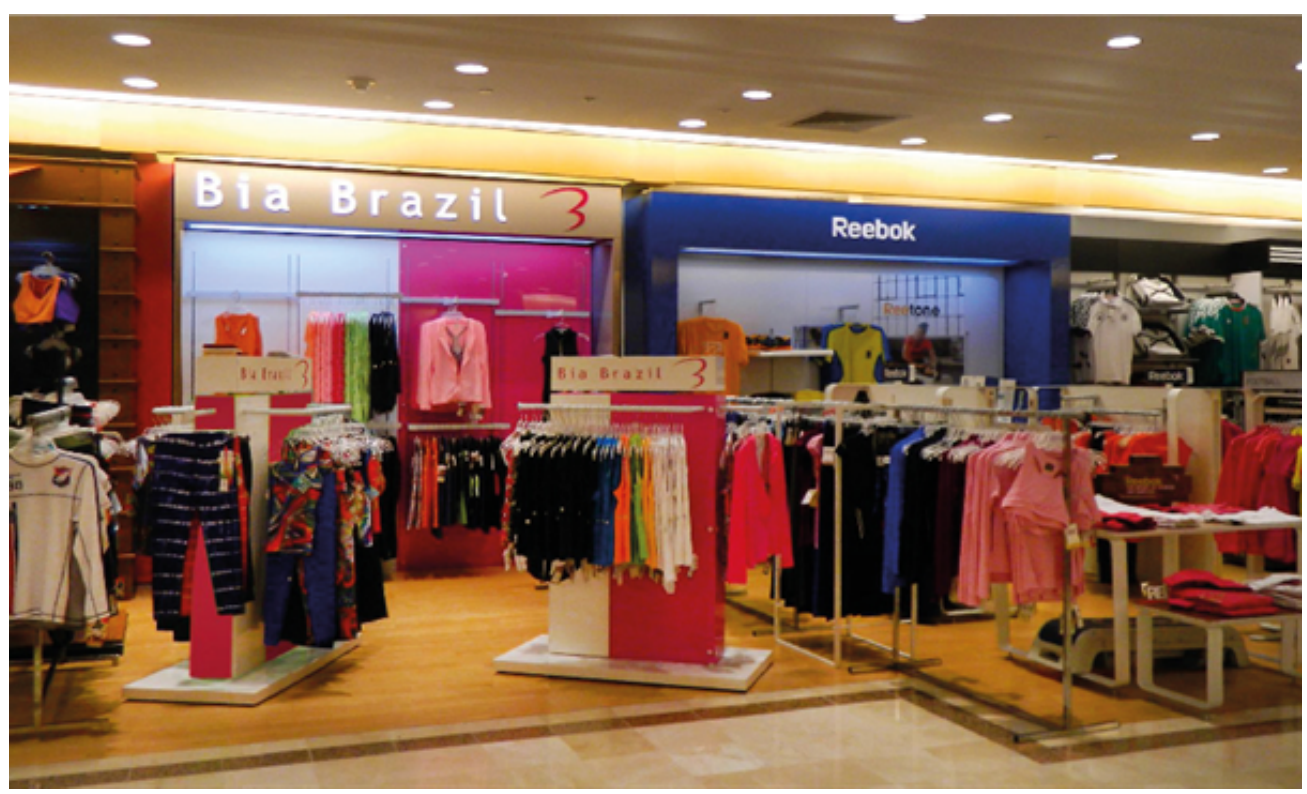

Figure 2. Bia Brazil corner in a department store.

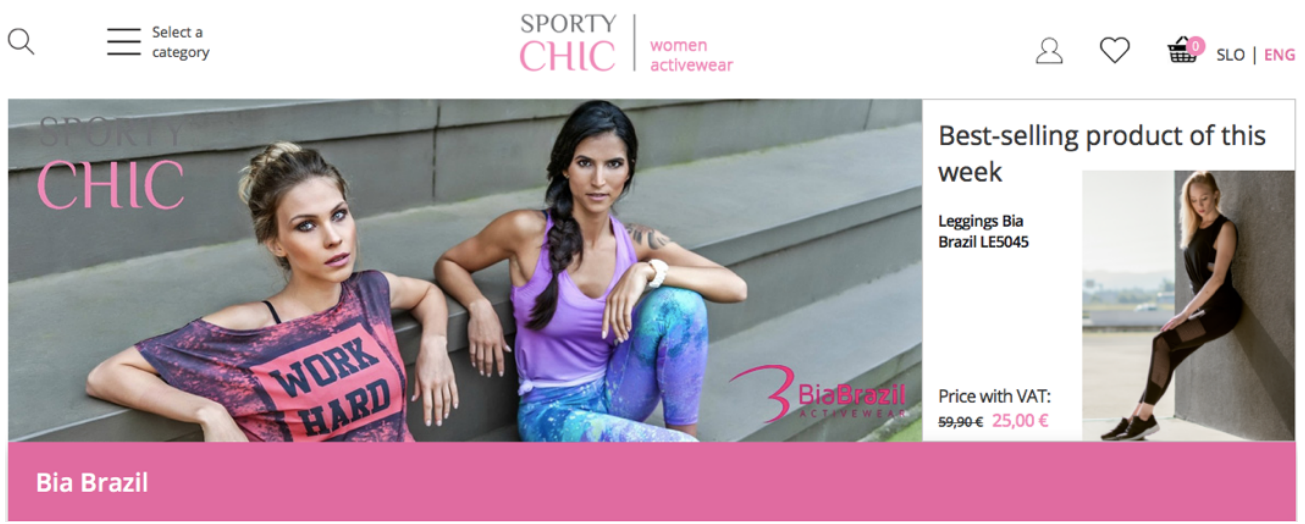

Figure 3. Bia Brazil's client website.

In addition, the company has a showroom in the United States and Portugal. Initially, the unit in the United States was focused on B2B and has been managed by their first client in the United States. In 2019, they opened a showroom focusing on $\mathrm{B} 2 \mathrm{C}$. The one in Portugal is managed by Bia Brazil and was opened focusing on the whole European market. A third showroom opened in Dubai in 2020. In the future, the company is planning to turn this showroom as a hub for the world. The idea is to have just one website, where the clients will identify their country, and be directly connected with one of these hubs.

Another entry mode is franchise stores. These stores are commercial outlets that only sell Bia Brazil products. To assure that the standard would be followed, these investors sign a franchise agreement that contains all the rules regarding the design of the store, the image used, and the main sales procedures.
These investors paid an amount at the signing that would also include a local training and support at the beginning of the operations. After that, Bia Brazil does not require any more payments and its profits came from the exports to the franchise store. These franchise stores are located in Finland, Paraguay, Portugal, Mexico, United States, Lebanon, and Croatia. By the end of 2017, the company signed contracts for future stores in Spain and Iran. These stores have a brand licensing, and the process involves the adoption of a standardized image project and the sending of a team for training in the target country. With this business model, the main financial gain to Bia Brazil comes from the export of products, which represents $90 \%$ of the company's revenues.

Even when working with a large number of destinations, customization is an important innovative factor for international competitiveness. To market a product in a 
specific environment, the company considers, among other factors, the culture of the country. To understand local culture, Bia states that it is important to visit gyms, parks, and other places where women engage in athletic activities. She also trusts reports developed by trends' agencies. Doing that, Bia Brazil is able to follow local and global activewear trends. For example, considering the recent exports to UAE and the identified potential in Muslim countries, the company is currently searching for more knowledge about Muslim athletes to define how to create a specific line.

Another customization is regarding sizes. To define the size change needs, every time a client from a new country starts to do business with Bia Brazil, the company offers samples in sizes small, medium, and large. Bia requests the client to use the samples to identify the required changes. As Beatriz highlights, it is not about just cutting a part of the outfits; they need to be redesigned in order to keep the shape of every product. For example, Japanese women have a different body shape than the Brazilians, so products that suit one may not suit the other.

Beatriz believes it is necessary to create specific portfolios for different countries, considering the capacity and availability of production as well as local preferences and cultural issues. Bia Brazil develops portfolios with more than 200 options every season, considering the design and color options. Based on these, the clients choose what they want, and they manufacture the products using the client's previously defined shape for each country. All the feedbacks received from the clients support the development of knowledge about different countries, which is used for the future collections to create products more attuned to different cultures.

According to Beatriz, innovation is important to differentiate itself from competitors, because the 'basics' are made by many companies, and what attracts consumers is, besides quality, the variety of products. Thinking about this, Bia Brazil focused on design as a differentiation factor for its products, compared to other products found in the market.

However, it is not enough just to have a great variety of products. It is necessary to innovate constantly. Considering the market in which it operates, Beatriz believes that the biggest innovation in active fashion is the fabric used to make the clothes. Many of these materials are made for professional athletes, with sun protection, faster heating, anti-odor materials, among other unique features. These products are developed in partnership with suppliers. In addition to these characteristics, the material must be adapted to the needs of the users. For example, anti-odor tissue is extremely expensive and does not have elasticity, which is critical for the movements performed. Thus, it was necessary to find ways to use these innovations in such a way that customers perceive their value. Therefore, it is not enough to offer products with differentiated design, and it is necessary to look for alternatives that are innovative and, at the same time, have adequate utility perceived by the customers.

An important competitive advantage comparing with globally known brands, such as Nike and Reebok, is the use of polyamide as a raw material rather than polyester. Polyamide is a higher quality material, even though it is more expensive. Polyamide allows more perspiration during physical activity, while at the same time having greater durability, both in the fabric itself and in maintaining the characteristics of the product - for example, when washing with hot water. The quality may not attract the first purchase of those who have no knowledge of differentiating the fabric but leads to customer retention due to the quality. As the manufacturing costs in Brazil are high, Beatriz affirms that she needs to invest in more quality products to reduce the impact of this cost at the final prices.

Regarding innovation in design, the company highlights a reversible woman top launched in 2017. The top is one of the most expensive items among activewear and, in the same product, it is possible to offer two options, representing an added-value product for the consumer of Bia Brazil's products. Although it was the first reversible model, the company is aware that the design will be quickly imitated by competitors, and this is a typical competitive reaction in the market.

Regarding product-related innovations, other actions have been developed by the company. In 2016, Bia Brazil focused on strengthening the partnership with its clients through the creation of a brand manual. The manual is related to the process of standardizing international stores, as well as to the renewal of the company's visual identity.

In 2017, the company changed its visual identity through the Design Export Program - developed in partnership with Apex-Brasil and the Centro Brasil Design (CBD). Packaging was standardized so the brand name is always presented in the same way for clients, shopkeepers, representatives, and final customers. Training bags, plastic bags, tags, paper bags, and gift boxes had their design changed in order to become means of communication with the brand (Figure 4). The company Néktar Design, responsible for the project, used the concept of Pink Power to develop this new identity. A market research identified the need to change the presentation, which was based on an image of the Brazilian female coming from abroad. The new design changed the focus to the strength of the women's movement, through the image of Brazilian women with confident attitude and protagonism. According to the manager of the design company, "the brand appropriates the color pink as a strong element of its identity. However, it is not a delicate rose, it is a strong, striking, powerful rose. The pink rose symbolizes the woman, but not the woman as a fragile sex, but the woman with confident attitude, a protagonist. We call Pink Power the visual appeal of black-and-white photos with a few highlights illuminated with pink". 


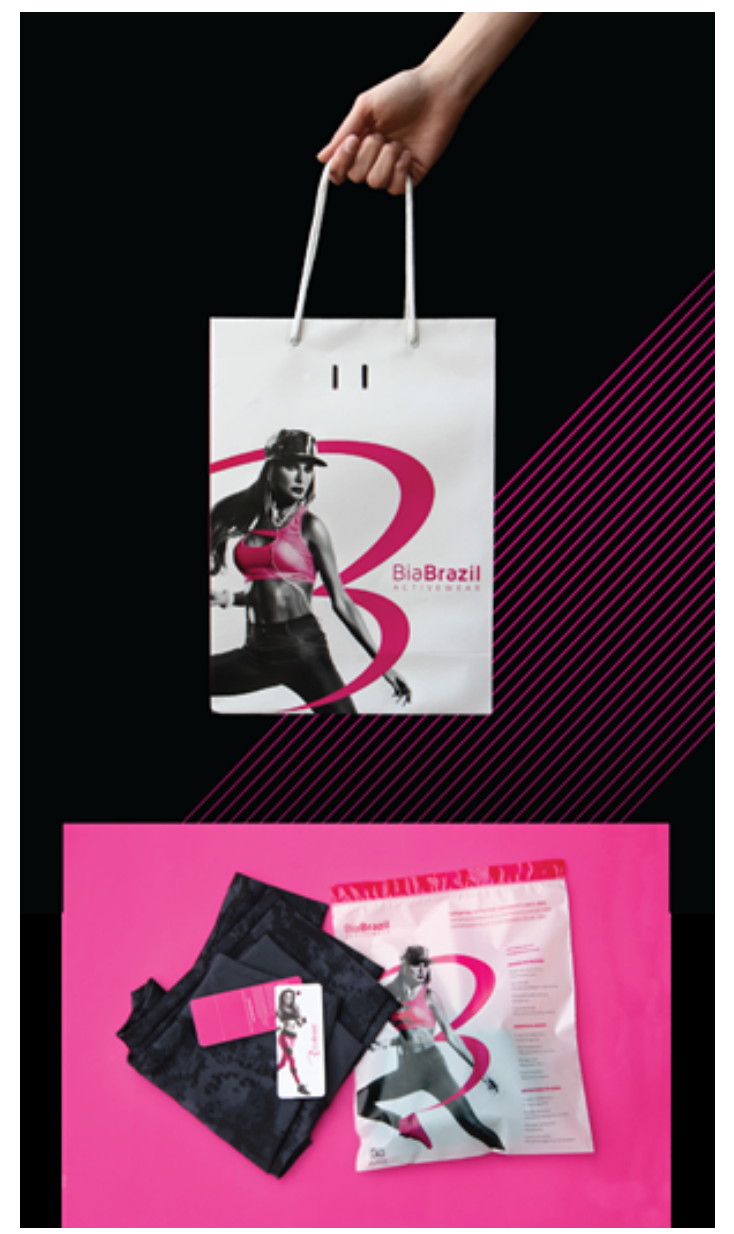

Figure 4. New brand strategy.

Over the years, the company has received many awards, notably:

Talentos Empreendedores - Segmento Exportador (Talentos Empreendedores - Export Segment) in 2005 and 2006; Movimento Brasil Competitivo in 2006; Exportação ADVB in 2007 and 2008; Prêmio Apex-Brasil - Melhor Ação Internacional de Marca (Best International Brand Action) in 2010, finalist, alongside Natura and O Boticário; Destaque Mercadológico ADVB in 2011; Prêmio ADVB - Segmento Têxtil (Textile Segment) in 2015; Exportador de Ouro RS in 2015; Destaque Mercadológico ADVB in 2016; Prêmio ADVB - Segmento Textil (Textile Segment) in 2017; Exportador de Ouro RS in 2017; Destaque Mercadológico ADVB in 2017; Oscar da Exportação in 2018.

\section{THE FIRST PHYSICAL STORE IN BRAZIL AND FUTURE PROSPECTS}

Although the company has excelled in the international market through different entry modes, Bia Brazil has been using the e-commerce as the main distribution channel in Brazil for several years. To stand out locally, one of the company's actions was to develop bikinis for beauty contests, a product that was not part of its portfolio. For 18 years, Bia Brazil participated in the contest Summer Girl, promoted in Rio Grande do Sul state, and, since 2007, started to make the costumes for Miss Rio Grande do Sul state. The company made bikinis exclusively for these two events. Beatriz believes that it is imperative that organizations have flexibility in their portfolio to be able to innovate.

The company's first physical store was opened in 2016 in a shopping mall in the city of Porto Alegre, Rio Grande do Sul state. This unit was closed in April 2017. According to Beatriz, the opening of this store was not a wise decision of the company, mainly due to its chosen commercial location. The stores in this mall are more focused on the children and food markets. Although there was a large customer traffic in the mall, it did not represent the target market that Bia Brazil was looking for. In 2017, a new store was opened in another shopping center in the same city, this time in partnership with an investor with retail experience. In less than six months, a family member of the investor had a serious illness and the investor decided to leave business to take care of this family member. At the time, the investor offered Beatriz to stay with the store, but considering her previous experience, she realized that the best thing for Bia Brazil was to stay focused on B2B and e-commerce. Despite these two experiences, Beatriz keeps the goal of expanding its business in Brazil while the company continues to expand its international operations.

\section{BACK TO THE PRESENT MOMENT}

After telling Alice the history of Bia Brazil, Beatriz says: "Do you know that it was very nice to remember our trajectory so far? You made me relive these moments in my memory. Our internationalization process was intense. When things are underway, we do not always have the opportunity to reflect on the trajectory, as I did while I was telling you our history".

Alice was very happy after hearing the history of Bia Brazil: "I am even more fascinated by the company and by everything that has been achieved over time. It is an incredible story!"

Beatriz looks at Alice and the way she looks mesmerized with the history of Bia Brazil. Alice is a brilliant student; she just graduated with an undergraduate degree in business management and started an MBA two weeks ago. During the interview process, Alice showed motivation and an entrepreneurial spirit, with a strong background. Beatriz believes that she can help the company to meet new challenges. Thinking of that, Beatriz says: "That's true, Alice! And we never stop. We always need to go ahead and I'm counting on you now. Now we are looking to our domestic market and thinking about: How should a Brazilian company, successful in the international market, promote its growth in the domestic market? This is our challenge now and I need you to help us". 
Teaching Notes

\section{ABSTRACT}

This teaching case presents the company Bia Brazil, one of the leading Brazilian exporters of activewear, founded in 1994 by a former gymnast, Beatriz, with websites in Portuguese, English, and Spanish. In 1996, the first exports to Costa Rica took place. Over the years, the company has expanded its sales to over 40 countries. The company seeks the constant offer of new products that meet the requirements and demands of each country. Despite its international growth, the company's presence in the Brazilian market remains small. There have been two failed attempts at physical stores, and although it continues with only online sales in the domestic market, the entrepreneur seeks a model to grow inside Brazil. We recommend the use of the case in courses related to internationalization, more specifically to International New Ventures and Born Globals. Some connections with other classes can be made and are recommended with the case analysis.

Keywords: teaching case; internationalization; activewear; international new ventures; born globals.

\section{Educational objectives}

This teaching case was developed to be used in international business courses to study the internationalization of International New Ventures and Born Globals. The context of the case can be associated with the contents of internationalization theories, strategy, global operations, and entry modes. The case can be used to support the study of internationalization with undergraduate or MBA students.

\section{Data sources}

The main sources of data collection were two interviews with the founder and manager, Mrs. Beatriz Wilhelm Dockhorn, held at the company's site in the second half of 2017 and the first half of 2019. The semi-structured interview followed a series of questions that were complemented by other issues that emerged in the conversation. Besides the interview, the occasion allowed a visit to the company's factory and the contact with the products. During this visit, an informed consent term was signed for the research and the use of the company name. In addition to the primary data collected during the interview and from the visit to

\section{RESUMO}

Este caso de ensino apresenta a empresa Bia Brazil, uma das empresas brasileiras líderes em exportação do mercado de roupas esportivas, fundada em 1994 por uma ex-ginasta, Beatriz, com sites em português, inglês e espanhol. Em 1996, ocorreu sua primeira exportaçáo para a Costa Rica. Ao longo dos anos, a empresa expandiu sua operação para mais de 40 países. A empresa busca a oferta constante de novos produtos adequados aos requisitos e demanda de cada país. Apesar do crescimento internacional, a presença da empresa no mercado brasileiro permanece pequena. Houve duas tentativas fracassadas de abertura de lojas físicas e, apesar de continuar vendendo no mercado doméstico apenas pela internet, a empreendedora continua a busca por um modelo para crescimento no Brasil. Recomendamos o uso do caso em cursos relacionados com teorias de internacionalizaçáo, mais especificamente International New Ventures (Empreendedorismo Internacional) e Born Globals. Algumas conexôes com outros cursos podem ser feitas e são recomendadas na análise do caso.

Palavras-chave: caso de ensino; internacionalização; roupas esportivas; empreendedorismo internacional; born globals.

the organization, secondary data were obtained from publications presented at the references.

\section{Teaching plan proposal}

We recommend instructors to make the case available for students to read in advance. Considering the previous reading, we present a plan to conduct the class with four segments. The activities and estimated time of each segment are presented in Table 1.

In order to prepare students to theoretically discuss the case, instructors can recommend the reading of the publications of Cavusgil and Knight (2015), Cavusgil, Zou, and Naidu (1993), Coviello (2015), Coviello and Munro (1995), Gabrielsson, Kirpalani, Dimitratos, Solberg, and Zucchella (2008), Knight and Cavusgil (2004), McDougall, Shane, and Oviatt (1994), Oviatt and McDougall (1994), and Zahra (2005). 
Table 1. Teaching plan proposal.

\begin{tabular}{|c|c|c|}
\hline Segment & Activity & Estimated time \\
\hline Opening & $\begin{array}{l}\text { Instructors can begin the class with some general questions, for example: Who knew the company } \\
\text { previously? What is your personal opinion about the company and its products? This will allow } \\
\text { students to get involved in the class. }\end{array}$ & 10 minutes \\
\hline \multirow{2}{*}{$\begin{array}{l}\text { Warm-up } \\
\text { (assigned questions) }\end{array}$} & $\begin{array}{l}\text { We recommend that the class be divided into small groups of students to discuss the case based on } \\
\text { assigned questions such as: }\end{array}$ & \multirow[b]{2}{*}{15 minutes } \\
\hline & $\begin{array}{l}\text { What motivated the entrepreneur to start the business? } \\
\text { How was the internationalization process of the company? } \\
\text { Which entry modes were used by Bia Brazil to internationalize? }\end{array}$ & \\
\hline \multirow{4}{*}{$\begin{array}{l}\text { Plenary activity } \\
\text { (discussion questions) }\end{array}$} & Instructors can start the plenary activity based on the discussion questions $\mathrm{A}, \mathrm{B}, \mathrm{C}$, and $\mathrm{D}$. & \multirow{4}{*}{$\begin{array}{l}80 \text { minutes }(20 \\
\text { minutes for each } \\
\text { question) }\end{array}$} \\
\hline & $\begin{array}{l}\text { These questions focus on the analysis of the case based on the two aspects of internationalization: } \\
\text { International New Ventures and Born Globals. Instructors should present the questions and request } \\
\text { students to apply the academic literature to develop the answers. Instructors must conduct the } \\
\text { discussion with students. }\end{array}$ & \\
\hline & $\begin{array}{l}\text { A list of suggested references for the case analysis is presented after this table. Instructors can } \\
\text { recommend students to study these articles in advance in order to analyze the case. }\end{array}$ & \\
\hline & Considering time limitation, we recommend the discussion to be conducted in a large group. & \\
\hline \multirow{2}{*}{$\begin{array}{l}\text { Closing statement } \\
\text { (future directions) }\end{array}$} & $\begin{array}{l}\text { Question E can be used as closing statement focusing on the deductive use of the theory to analyze } \\
\text { the case. Afterwards, they can focus on the company's trajectory and its future prospects. }\end{array}$ & \multirow[b]{2}{*}{20 minutes } \\
\hline & $\begin{array}{l}\text { It is important to encourage students to think about future business strategies. We recommend } \\
\text { instructors to invite students to reflect on what they previously studied about the company and to use } \\
\text { their previous knowledge to analyze the situation. }\end{array}$ & \\
\hline
\end{tabular}

\section{Discussion questions}

Possible questions that can be asked to discuss the case:

a. For what reasons has the company already started operations aimed at the global market, rather than starting locally?

b. In what way did the presence of the manager as an international entrepreneur influence the internationalization process of Bia Brazil Activewear?

c. Starting from exports, Bia Brazil adopted different entry modes during the internationalization process. What are the possible entry modes for an internationalizing company such as Bia Brazil?

d. How does the company deal with the need for product adaptation and innovation in the internationalization process?

e. What difficulties do you believe Bia Brazil Activewear will face in order to consolidate itself with physical units in Brazil?

\section{Case analysis with literature support}

Before analyzing each question, we present a synthesis of the content that will be discussed in each question in Table 2 .

a. For what reasons has the company already started operations aimed at the global market, rather than starting locally?
Instructors may use this question to introduce a discussion regarding International New Ventures (INV) and Born Globals. They can ask students to answer the same question with each of the two theoretical perspectives.

The International New Venture approach based on Coviello and Munro (1995), McDougall et al. (1994), Oviatt and McDougall (1994), and Zahra (2005) focuses on companies that have a proactive international strategy based on value added issues, instead of assets owned. This is the case of Bia Brazil, which developed alternative governance structures with the use of different entry modes, established foreign location advantages through partnerships, while keeping control over unique resources (as design and brand). These three main characteristics of INV can be explored in a discussion in class and the students can be requested to explain these issues based on the case. For example, in USA, Bia Brazil has a partner that manages its website and is responsible for the distribution not just at the local market, but also for nearby countries. The company decided to adopt that structure because of the knowledge of the partner and their long-term relationship. But in Portugal, Bia Brazil decided to have its own showroom. These differences can be explored in a discussion in class and the use of representatives, the franchise stores, and the department stores can be compared in order to understand why the company decided to have different strategies as a way to increase the value of the business worldwide. 
Table 2. Synthesis of the analysis of the discussion questions.

\begin{tabular}{ll}
\hline Question & Main topics to be discussed \\
\hline & $\begin{array}{l}\text { INV: the proactive international strategy based on value added issues; the development of alternative control } \\
\text { over unique resources; early stages - experience and the network of the founders; later stages - continuous } \\
\text { use of network relationships to pursue market opportunities. }\end{array}$ \\
$\begin{array}{ll}\text { a) For what reasons has the company } \\
\text { already started operations aimed at } \\
\text { the global market, rather than starting } \\
\text { locally? }\end{array}$ & $\begin{array}{l}\text { Born Global: rapidly internationalization; flexibility as a competitive advantage; innovative capacity; the } \\
\text { development of specific types of knowledge that drove the development of organizational capabilities to support } \\
\text { the internationalization and performance in international markets; market opportunities worldwide; the } \\
\text { emergence of global niches; technological developments in communications; the emergence of global networks } \\
\text { and alliances; organizational capabilities and personal connection of the founder-entrepreneur. }\end{array}$
\end{tabular}

b) In what way did the presence of the manager as an international entrepreneur influence the internationalization process of Bia Brazil Activewear?

c) Starting from exports, Bia Brazil adopted different entry modes during the internationalization process. What are the possible entry modes for an internationalizing company such as Bia Brazil?

d) How does the company deal with the need for product adaptation and innovation in the internationalization process?

e) What difficulties do you believe Bia Brazil Activewear will face in order to consolidate itself with physical units in Brazil?
INV: the concept of 'the next generation of founders'; international experience; open and different mindset; 'an unusual constellation of competencies' - networks, knowledge, and background; international business experience with knowledge about global environment.

Born Globals: global vision; capabilities at the strategy and organizational levels; the view of the world as 'their market'.

Entry modes: export; franchise stores; strategic alliance (USA partner); showroom in Portugal

Company characteristics: firm's international experience; export sales goal for the venture; entry scope.

Product/industry characteristics: technology orientation of industry; product uniqueness; cultural specificity of product; type of product.

Export market characteristics: similarity of legal requirements; competitiveness of export market; product familiarity of export customers.

Lack of experience with physical retail activities.

Potential challenges to manage the new stores, especially regarding logistics and promotion.

Limited human resources.
To support the discussion, instructors should emphasize that the experience and the network of the founders is a key motivation for INV in early stages, and the continuous use of network relationships to pursue market opportunities in later stages of internationalization. We recommend instructors to use the partner in USA to discuss the importance of networks and how Bia Brazil has built them. In this situation, Beatriz used the failure of a competitor to find an opportunity. She builds a business relationship showing that Bia Brazil is different. Over time, they increased the partnerships and the change in focus from $\mathrm{B} 2 \mathrm{~B}$ to $\mathrm{B} 2 \mathrm{C}$ can be explored here.

Regarding Born Global perspective, we recommend the use of Knight and Cavusgil (2004), Gabrielsson et al. (2008), and Cavusgil and Knight (2015) to support the discussion. According to this approach, Born Global firms internationalize relatively rapidly - often three years or less; and this is the case of Bia Brazil. The fact that Beatriz started the company with a website in three languages can be explored here. Bia Brazil remains a small company and it gives the managers flexibility as a competitive advantage. They grew through the establishment of partnerships and it allowed Bia Brazil to explore resources from their local partners. Another important characteristic of Born Globals is to be innovative and the development of specific types of knowledge that drove the development of organizational capabilities to support the internationalization and performance in international markets. To explore the importance of innovation at Bia Brazil, we recommend instructors to focus on product innovation. Regarding the learning process to develop new organizational capabilities, instructors can request students to develop a timeline with the main important events in the company's history highlighting what happened and what the company learnt from that. As an example, we highlight three situations, but more can be explored: (a) the first export to Costa Rica and the problem with products quality; (b) the foundation of Apex-Brazil and the opportunity to attend international fairs with managers from more experienced companies; (c) the fire in 2008 and the support from international clients.

Born Global theories also support the discussion regarding the reasons for the early internationalization of Bia Brazil. Aspects as market opportunities worldwide, the emergence of global niches, technological developments in communications, the emergence of global networks and alliances, organizational capabilities, and a personal connection of the founder-entrepreneur are presented by Knight and Cavusgil (2004), Gabrielsson et al. (2008), and Cavusgil and Knight (2015) as motivation for the internationalization 
of new ventures. Instructors can discuss each of these aspects with students; for example, how Beatriz identified activewear market opportunities worldwide, exploring her experience as an athlete, her life experience, and her personal connections before she started the business. The emergence of global niches includes the focus on more designed activewear specifically designed for women and on products' technology. Aspects as fabrics and design can be explored here to highlight the changes in the market segment, and the internet as used by Beatriz in early years to drive Bia Brazil business worldwide. The students may be younger than Bia Brazil and a discussion regarding the changes in communication technologies over years can be explored here in a way to explain the importance of these technologies to drive the internationalization of companies. Beatriz had no experience with business before she started the company, but she had an international exposure as an athlete, and she used this background from sport in her business. Zahra (2005) argues that it may take a long time for gestation before the company is officially launched. Even though we cannot assure that Beatriz was already thinking about opening a business after retiring from sport, it is clear that she used all her knowledge to create the company.

b. In what way did the presence of the manager as an international entrepreneur influence the internationalization process of Bia Brazil Activewear?

We recommend instructors to use the case to explore the concept of 'the next generation of founders' presented by Coviello (2015). Potential use of this question is to ask students to develop a profile of the main characteristics presented by Coviello (2015) and characteristics of Beatriz.

Beatriz had a good international experience before she started the company and has since maintained and improved her experience by attending international fairs, visiting her actual partners and potential ones, searching for more fashion trends, and technologies, for example. She had difficulties and lost money in the beginning as a consequence of the lack of knowledge. Instead of complaining and giving up on selling abroad, the experience was used as an opportunity to learn and improve the company's capabilities.

Beatriz presented an open mindset to deal with special requirements in each country. This is a characteristic identified by Coviello (2015): a different mindset. She always accepted that her product will never be perfect for everyone, and her mindset was open for product adaptation. Actually, to promote these adaptations, the company needed to learn what the customers want directly from them. To do so, the manager must have an open mindset for change. As presented in the case, she uses the international experience to improve innovation in the company's products. The development of new technologies through partnerships, and even the products' adaptation with franchisees and distributors from abroad, shows that the business was developed based on open-minded innovation, another characteristic highlighted by Coviello (2015).

The analysis at this point can also focus on what McDougall et al. (1994) called as "an unusual constellation of competencies" (McDougall et al., 1994, p. 479). According to these authors, the founder of an INV was seen as a professional able to identify opportunities from establishing ventures that operate in the global market because of his competences - networks, knowledge, and background - that he have developed from his earlier activities. At the beginning of the case, Beatriz explained the problems she identified as the lack of specific designs for women and the standardization of the outfits for men and women. The capability to identity the market opportunity can be discussed here. Aspects of the clothes, such as fabric quality and technological aspects, can also be included in the analysis.

To increase the discussion, instructors can request students to make a comparison of the role of the decision-makers in the internationalization process. Following the INV approach, the company's founders are usually people with international business experience with knowledge about global environment. Their personal relations represent an essential element for the development of the firm (Coviello \& Munro, 1995; McDougal, Shane, \& Oviatt, 1994; Oviatt \& McDougall, 1994; Zahra, 2005). The Born Global approach highlighted that founders and managers usually have a global vision, and capabilities at the strategy and organizational levels (Cavusgil \& Knight, 2015; Gabrielsson, Kirpalani, Dmitratos, Solberg, \& Zuchella, 2008; Knight \& Cavusgil, 2004).

Another suggestion is to investigate the assumption of Cavusgil and Knight (2015) to whom the founders of born global firms explicitly or implicitly view the world as their market place. This is a consequence of the fact that the rise of these firms coincided with the emergence of the modern era of globalization. These managers discovered the feasibility of reaching a transnational profile of customers worldwide. If time is available, instructors can establish a connection point here with customer segmentation and positioning. We do not increase this discussion here but according to the class contents, this can be an opportunity to explore the case with other subjects.

c. Starting from exports, Bia Brazil adopted different entry modes during the internationalization process. What are the possible entry modes for an internationalizing company such as Bia Brazil?

Bia Brazil started operating abroad with exports, and this entry mode remain used by the company, especially as a way to support other entry modes. The decision of the company to focus on B2B led the company to use other entry modes such as strategic alliance with a North American partner, franchised stores worldwide and, more recently, a foreign direct investment in Portugal. Instructors here can motivate their students to develop a comparative analysis of each entry mode as follows in Table 3. 
Table 3. Case analysis - Entry modes and the internationalization theories.

\begin{tabular}{|c|c|c|c|}
\hline Entry mode & International New Ventures & Born Globals & General comments \\
\hline Export & $\begin{array}{l}\text { The choice of the activities that will be } \\
\text { internationalized depends on the network } \\
\text { developed by the firm and its need of } \\
\text { assets from partners. } \\
\text { Bia Brazil centralized the production in } \\
\text { Brazil. Export remains as a consequence. }\end{array}$ & $\begin{array}{l}\text { The maintenance of the focus on sales } \\
\text { through exports can be supported by the } \\
\text { use of other entry modes. }\end{array}$ & \multirow[b]{2}{*}{$\begin{array}{l}\text { Regarding the development of networks } \\
\text { with the support of Apex-Brazil, we did } \\
\text { not find support to analyze the case based } \\
\text { on INV and Born Globals approaches. } \\
\text { If instructors want to deeply explore this } \\
\text { issue we recommend the investigation of } \\
\text { the Networks approach. }\end{array}$} \\
\hline Franchise stores & $\begin{array}{l}\text { The selection of the entry mode is shaped } \\
\text { not only by the company interest. It } \\
\text { considers interests of other players in the } \\
\text { network of relationships. Governance } \\
\text { structures such as licensing, franchising, } \\
\text { strategic alliances, and networks are } \\
\text { adopted. } \\
\text { Bia Brazil adopted the use of franchise } \\
\text { stores in partnerships with local } \\
\text { entrepreneurs as a way to explore their } \\
\text { knowledge regarding the local market } \\
\text { and retail - a very important asset in the } \\
\text { business. } \\
\text { Standardization of the company image and } \\
\text { the customization of products according } \\
\text { with their partners' feedback on products } \\
\text { design. }\end{array}$ & $\begin{array}{l}\text { Companies search for market } \\
\text { opportunities. } \\
\text { Bia Brazil internationalization process } \\
\text { was to conduct market selection in a non- } \\
\text { systematic way. } \\
\text { The search for opportunities worldwide } \\
\text { that could be interesting for the company. }\end{array}$ & \\
\hline $\begin{array}{l}\text { Strategic alliance } \\
\text { (USA partner) }\end{array}$ & $\begin{array}{l}\text { In order to increase operation abroad, } \\
\text { companies need to have some activities } \\
\text { coordinated across countries. Bia Brazil } \\
\text { uses its partner in USA not just to attend } \\
\text { to the local market, but also as a platform } \\
\text { to sell to other countries. } \\
\text { Brazil USA works as an instrument to } \\
\text { sell the company worldwide, as many } \\
\text { new clients can get in contact with the } \\
\text { company using the US website. }\end{array}$ & $\begin{array}{l}\text { Alliances and joint ventures with key- } \\
\text { partners are established to support exports. } \\
\text { Companies gradually develop distributors } \\
\text { abroad. } \\
\text { The partnership developed with the North } \\
\text { American representative evolved from a } \\
\text { B2B client to strategic partner responsible } \\
\text { for the company's website and distribution } \\
\text { in USA and surrounding countries. }\end{array}$ & \\
\hline $\begin{array}{l}\text { Showroom in } \\
\text { Portugal }\end{array}$ & $\begin{array}{l}\text { INV's theory does not state anything } \\
\text { explicitly about foreign direct investments. } \\
\text { Besides that, we must consider } \\
\text { that this theory supports that the } \\
\text { development of the firm depends on its } \\
\text { internationalization efforts, so it tends } \\
\text { to be intense depending on the need for } \\
\text { assets from abroad. } \\
\text { Knowing more about an international } \\
\text { market may be a need identified by Bia } \\
\text { Brazil. Once more, even though it is not } \\
\text { clear in the case, instructors can encourage } \\
\text { students to think about it. }\end{array}$ & $\begin{array}{l}\text { Born global theory does not state anything } \\
\text { explicitly about foreign direct investments. }\end{array}$ & $\begin{array}{l}\text { The establishment of Foreign Direct } \\
\text { Investments is not well-explained by the } \\
\text { theories used to analyze the case. } \\
\text { At this point, we can recommend } \\
\text { instructors to invite students to } \\
\text { search for other theories that can be } \\
\text { used at this analysis, as the Uppsala } \\
\text { Internationalization Process Model. } \\
\text { According to this approach, companies } \\
\text { starts to internationalize through exports, } \\
\text { followed by contractual agreements as } \\
\text { joint ventures. As the company gains } \\
\text { experimental knowledge in foreign } \\
\text { markets, wholly owned investments } \\
\text { abroad are made. }\end{array}$ \\
\hline
\end{tabular}

d. How does the company deal with the need for product adaptation and innovation in the internationalization process?

The theory regarding Born Globals considers that these companies tend to market value-added offering with innovative, cutting edge, differentiated, and unique products, resulting from advantages in science, technology, and/or design
(Cavusgil \& Knight, 2015; Gabrielsson et al., 2008; Knight \& Cavusgil, 2004). We recommend instructors to explore these aspects carefully analyzing product using the framework proposed by Cavusgil et al. (1993). This is a traditional model to analyze product adaptation to exports, and it explores company characteristics, product/industry characteristics, and export market characteristic. Theses aspects are analyzed in Table 4. 
Table 4. Case analysis — Product analysis.

\begin{tabular}{|c|c|c|}
\hline Dimension & Variable & Bia Brazil \\
\hline \multirow{6}{*}{$\begin{array}{l}\text { Company } \\
\text { characteristics }\end{array}$} & \multirow{3}{*}{$\begin{array}{l}\text { Firm's international } \\
\text { experience }\end{array}$} & A strong international experience supports the efforts to adapt products. \\
\hline & & Several changes have been required since the beginning of their exports. \\
\hline & & $\begin{array}{l}\text { The willingness to adapt has influenced Bia Brazil strategy — to be open to adapt the products for } \\
\text { markets' need. }\end{array}$ \\
\hline & \multirow{2}{*}{$\begin{array}{l}\text { Export sales goal for the } \\
\text { venture }\end{array}$} & Export is the main revenue source. \\
\hline & & The company knows that it needs to offer what customers want to be competitive. \\
\hline & Entry scope & $\begin{array}{l}\text { Products represent a potential scope economy for their retail customers. } \\
\text { They attend to several needs of athletes or practitioners of physical activities. } \\
\text { Regarding export's costs, different products can be exported together. }\end{array}$ \\
\hline \multirow{9}{*}{$\begin{array}{l}\text { Product/industry } \\
\text { characteristics }\end{array}$} & $\begin{array}{l}\text { Technology orientation } \\
\text { of industry }\end{array}$ & $\begin{array}{l}\text { The activewear industry has improved technology in the last decades. } \\
\text { Examples of technologies: anti-odor, breathable, and more comfortable fabrics for physical activity. }\end{array}$ \\
\hline & Product uniqueness & $\begin{array}{l}\text { Activewear outfits cannot be considered unique products. Sometimes their raw materials and the way } \\
\text { they are used can give uniqueness for the company. }\end{array}$ \\
\hline & \multirow{4}{*}{$\begin{array}{l}\text { Cultural specificity of } \\
\text { product }\end{array}$} & The main driver of product adaptation for Bia Brazil products. \\
\hline & & They need to adapt colors, patterns, sizes, and even design to be competitive in many countries. \\
\hline & & The cultural specificity changes every year and it is mandatory for the company to follow the trends. \\
\hline & & $\begin{array}{l}\text { The need for religious adaptation occurs less often. However, when it happens, products need to be } \\
\text { adapted significantly. }\end{array}$ \\
\hline & \multirow{3}{*}{ Type of product } & The way women want to dress for exercise changes very frequently. \\
\hline & & New designs and fashion trends require the development of new products constantly. \\
\hline & & In addition to belonging to the same segment, activewear, the specific products must be changed. \\
\hline \multirow{3}{*}{ Export market } & $\begin{array}{l}\text { Similarity of legal } \\
\text { requirements }\end{array}$ & There is a low level of legal differences in different countries. \\
\hline & $\begin{array}{l}\text { Competitiveness of } \\
\text { export market }\end{array}$ & $\begin{array}{l}\text { Quality and the capability to launch new patterns and products are the main competitive advantages. } \\
\text { The competitiveness of Bia Brazil depends on its capacity to innovate, not product adaptation. }\end{array}$ \\
\hline & $\begin{array}{l}\text { Product familiarity of } \\
\text { export customers }\end{array}$ & $\begin{array}{l}\text { Activewear outfits are used worldwide, especially influenced by the fashion industry and the export } \\
\text { markets. Bia Brazil does not need to promote product familiarity to its customers. }\end{array}$ \\
\hline
\end{tabular}

e. What difficulties do you believe Bia Brazil Activewear will face in order to consolidate itself with physical units in Brazil?

This is a very important moment in the case analysis, as instructors need to change from a deductive perspective, through the use of theories to analyze the case, to a moment when students must be encouraged to present their opinions and suggestions for Bia Brazil. In the sequence, we present a list of topics that can support the discussion. Instructors can briefly introduce them to motivate students to present their own consideration.

The first issue to be discussed is the fact that Bia Brazil had no experience with physical retail activities. Where the company has physical stores, they are always operated by the local partners. Even though the company may have learnt with these partnerships, no one can affirm that it will support the development of B2C strategies. Bia Brazil already has some knowledge with e-commerce in Brazil, but brick-and-mortar retailing was never the focus of the company. Looking at two previously experiences in Brazil, Bia Brazil will have a difficult time to include the physical B2C strategy.

Another issue is how to manage the new stores, especially regarding logistics and promotion. Inside Brazil, the company has experience to ship only e-commerce orders. In these cases, each client represents a destination point and a regular frequency is not established with them. When you have stores to supply, you need to have a strong plan to support it, considering not just the transportation process but also how to deal with sales forecast. Usually it is very expensive to have a large inventory at the stores, and the retailers need new shipments very often. The retailers do not usually make the same order for a long time; they order according to the customers' preferences, which could change very fast and, to avoid the risk of not being able to offer the most desired products, they need suppliers that could supply them very fast and with the availability of the desired collection of products. 
If instead of using a retailer as a partner, Bia Brazil has to develop new knowledge about how to do it by itself, probably it will be more difficult, as the first experience presented at the case already highlighted. But if, besides that, Bia Brazil decided to manage the units in Brazil, the company will also face a challenge to deal with promotion for the final customers, including how to manage it on festive dates, for example.

A last important issue to highlight is that Bia Brazil has limited human resources. Beatriz is responsible for all strategic decisions, and she controls everything. It would be very complicated if she decided to do the same in Brazilian market. Actually, that represents a great risk for the international operation, as she may need to reduce the time she dedicates to the foreign operations.

\section{REFERENCES}

Cavusgil, S. T., \& Knight, G. (2015). The born global firm: An entrepreneurial and capabilities perspective on early and rapid internationalization. Journal of International Business Studies, 46, 3-16. https://doi.org/10.1057/jibs.2014.62

Cavusgil, S. T., Zou, S., \& Naidu, G. M. (1993). Product and promotion adaptation in export ventures: An empirical investigation. JournalofInternational Business Studies, 24(3), 479-506. https://doi.org/10.1057/palgrave.jibs.8490242

Coviello, N. (2015). Re-thinking research on born global. Journal of International Business Studies, 46(1), 17-26. https://doi.org/10.1057/jibs.2014.59

Coviello, N. E., \& Munro, H. J. (1995). Growing the entrepreneurial firm: Networking for international market development. European Journal of Marketing, 29(7), 4961. https://doi.org/10.1108/03090569510095008

Gabrielsson, M., Kirpalani, V. H. M., Dimitratos, P., Solberg, C. A., \& Zucchella, A. (2008). Born global: Propositions to help advance the theory. International Business Review, 17(4), 385-401. https://doi.org/10.1016/j.ibusrev.2008.02.015
Please consider that we just presented a brief list of issues that can be discussed by students. Instructors should not limit the discussion as students can bring 'fresh air' to the classroom. At this moment, once more, encourage students to research on Bia Brazil. As the case presented the company real name, there is plenty of information available online that can bring new data for the discussion.

\section{ACKNOWLEDGEMENTS}

The authors would like to offer special thanks to the reviewers. Their contributions were extremely important for the improvement of this teaching case.

Knight, G. A., \& Cavusgil, S. T. (2004). Innovation, organizational capabilities, and the born-global firm. Journal of International Business Studies, 35, 124-141. https://doi.org/10.1057/palgrave.jibs.8400071

McDougall, P. P., Shane, S., \& Oviatt, B. M. (1994). Explaining the formation of international new ventures: The limits of theories from international business research. Journal of Business Venturing, 9(6), 469-487. https://doi.org/10.1016/0883-9026(94)90017-5

Oviatt, B. M., \& McDougall, P. P. (1994). Toward a theory of international new ventures. Journal of International Business Studies, 25(1), 45-64. https://doi.org/10.1057/palgrave.jibs.8490193

Zahra, S. A. (2005). A theory of international new ventures: A decade of research. Journal of International Business Studies, 36, 20-28. https://doi.org/10.1057/palgrave.jibs.8400118 


\section{Authorship}

\section{Masaaki Kotabe}

Temple University, The Fox School of Business

1801 Liacouras Drive, 559 Alter Hall (006-00), 19122-6008, Philadelphia, PA, United States.

E-mail address: mkotabe@temple.edu

(D) https://orcid.org/0000-0002-1078-4844

\section{Moema Pereira Nunes*}

Universidade FEEVALE, Instituto de Ciências Sociais Aplicadas RS-239, no 2755 , Vila Nova, 93352-000, Novo Hamburgo, RS, Brazil.

E-mail address: moemanunes@hotmail.com; moema@feevale.br

(D) https://orcid.org/0000-0002-9729-9074

\section{Fernanda Kalil Steinbruch}

Universidade Federal do Rio Grande do Sul, Escola de Administração

Rua Washington Luiz, no 855, Centro Histórico, 90010-460, Porto Alegre, RS, Brazil

E-mail address: fernanda_ks@hotmail.com

(D) https://orcid.org/0000-0001-8059-2752

* Corresponding Author

\section{Funding}

There are no funders to report for this article.

\section{Authors' Contributions}

$1^{\text {st }}$ author: conceptualization (supporting); formal analysis (supporting); writing-review \& editing (supporting).

$2^{\text {nd }}$ author: conceptualization (lead); formal analysis (equal); investigation (equal); project administration (lead); writingoriginal draft (lead); writing-review \& editing (equal).

$3^{\text {rd }}$ author: formal analysis (equal); investigation (equal); writing-original draft (equal).

\section{Conflict of Interests}

The authors have stated that there is no conflict of interest.

\section{Copyrights}

RAC owns the copyright to this content.

\section{Plagiarism Check}

The RAC maintains the practice of submitting all documents approved for publication to the plagiarism check, using specific tools, e.g.: iThenticate.

\section{Peer Review Method}

This content was evaluated using the double-blind peer review process. The disclosure of the reviewers' information on the first page, as well as the Peer Review Report, is made only after concluding the evaluation process, and with the voluntary consent of the respective reviewers and authors. 